\title{
To Study the Genomic Fingerprinting of Relatedness in Strains of Bacillus Sp. by RAPD Analysis
}

\author{
Sasmita Das¹, Pratima Pradhan¹, Ajay Kumar Sahu² \\ 1Department of Biotechnology, Academy of Management \& Information Technology Khordha, Odisha, India \\ 2Department of Microbiology, Bangalore University, Bangalore, India
}

\begin{abstract}
The aim of the present investigation was to study the genomic adaptation of Bacillus sp. isolated from chromium contaminated environment and normal environment. For this purpose ten highly chromium resistant Bacillus sp. (CSB-1 to10) and ten normal Bacillus sp. (NB-1 to 10) were isolated from soil samples collected from mine and it's adjacent areas of Sukinda, Odisha. The genomic DNA was isolated from 20 Bacillus species and made free from contamination of RNA by RNAase treatment. The molecular weight of DNA from 20 Bacillus species were determined by comparing with $\lambda$ DNA. The genomic variation study of 10 chromium resistant and 10 normal strains of Bacillus was done by RAPD analysis. Among the 10 primers used only two OPT 01 and OPT 05 gave the amplification. OPT 01 primer gave lesser bands in normal Bacillus species than those obtained in chromium resistant Bacillus species. The presence of those DNA fragment band in chromium resistant Bacillus can be used as a molecular marker to identify chromium resistant Bacillus from normal Bacillus. These chromium resistant Bacillus species after further assessment of their potential to reduce the toxic hexavalent form to its nontoxic trivalent form can be exploited for the bioremediation of toxic and carcinogenic soluble hexavalent chromium containing industrial effluents.
\end{abstract}

\section{INTRODUCTION}

Chromium can exist in environment as Cr(III) or $\mathrm{Cr}(\mathrm{VI})$. $\mathrm{Cr}(\mathrm{VI})$ compounds are comparatively more toxic then $\mathrm{Cr}$ (III) due to their high solubility in water, rapid permeability through biological membranes and subsequent interaction with intracellular protein and nucleic acids. $\operatorname{Cr}(\mathrm{VI})$ is toxic, carcinogenic and mutagenic to animals as well as humans ant is associated with decreased plant growth and changes in plant morphology. Improper handling and storage of chromium-laden effluents or wastes has led to $\mathrm{Cr}(\mathrm{VI})$ contamination of surface water, groundwater, soil and sediment (Desjardin et al., 2003), which has posed acute and chronic health risks to animals and humans (Marsh ad McInereny,2001;McLean and Beveridge,2001). Focusing on it's toxicity and exposure potential, the United States Environmental Protection Agency (USEPA) lists hexavalent chromium as a priority pollutant.

Many researchers has explored the microorganisms such as Aerococcus sp., Arthrobacter sp., Bacillus sp, and Pseudomonas sp. have the potent of affecting soil water and hence the environment of the chromium contaminated area. They have also found that these microorganisms have a great resistant toward the $\mathrm{Cr}(\mathrm{VI})$ and hence play an important role in chromium bioremediation. Biological reduction of $\mathrm{Cr}(\mathrm{VI})$ using indigenous microorganism offer a new cost-effective and environmentally compatible technology (Camargo et al. 2005). For the reduction of $\mathrm{Cr}(\mathrm{VI})$, cells should be able to tolerate $\mathrm{Cr}(\mathrm{VI})$ otherwise cell growth is inhibited. Cr(VI) in bacterial cells is reduced by either physiological reducing agents (Glutathione) or reductase enzymes. $\mathrm{Cr}(\mathrm{VI})$-reducing bacteria have also been isolated and characterized from chromium contaminated soil , wastewater and industrial effluents. Among different bacterial species Bacillus sp. are the dominant chromium resistance species (Das et al., 2015). Molecular markers have been developed to track the survival and efficacy of specific bacteria that are used as inocula for bioremediation of contaminated soil (Webster's Dictionary). Genetic marker can be defined as any stable and inherited variation that can be measured or detected by a suitable method, and can be used subsequently to detect the presence of a specific genotype or phenotype other than itself, which otherwise is non measurable or very difficult to detect. Such variations occurring at different levels, i.e. at the morphological, chromosomal, biochemical or DNA level can serve as the genetic markers. Therefore the present work was aimed to study the genomic adaptation and fingerprinting of relatedness in strains of Bacillus species by RAPD analysis which were isolated from chromium contaminated environment and normal environment.

\section{MATERIALS AND METHODS}

Bacterial cultures

The bacterial strains were isolated from soil samples collected from mine and it's adjacent areas of Sukinda and some normal bacteria were isolated from normal soil samples of Bhubaneswar. All bacterial strains were isolated using nutrient agar (NA) medium 0 and preserved at $-80^{\circ} \mathrm{C}$ in $20 \%$ glycerol. Total 20 numbers of bacterial strains are used in this work. Out of 20 strains, 10 are chromium resistance Bacillus (CSB-1 to 10) and another 10 are normal Baccillus sp. (NB 1to 10).

\section{Isolation, purification and quantification of genomic DNA}

The genomic DNA of 20 Bacillus sp. was isolated using standard method Sambrook and Russell, (2001). The DNA bands were separated by $0.8 \%$ agarose gel electrophoresis. The RNA contamination was removed by RNAase treatment. $10 \mu \mathrm{l}$ of RNAase I $(10 \mathrm{U} / \mu \mathrm{l}$, one unit digests $10 \mathrm{ng}$ of RNA per second) was mixed to the DNA sample. It was then incubated for $1 \mathrm{hr}$ at $37^{\circ} \mathrm{C}$. Then the tube placed to cool and ethanol precipitation was done by adding $1 / 10$ volume of absolute ethanol and placed at $-20^{\circ} \mathrm{C}$ for $2 \mathrm{hr}$. Then the sample was centrifuged for $20 \mathrm{~min}$ at $4^{\circ} \mathrm{C}$. The supernatant was discarded and the pellet was washed with $70 \%$ chilled ethanol and centrifuged at $4^{\circ} \mathrm{C}$ for 3-5 minute. Then ethanol 
was discarded and air dried for few minutes. Then the pellet was resuspended with $100 \mu \mathrm{l}$ of TE buffer.

The purified genomic DNA of 20 Bacillus sp. was quantified against $\lambda$ DNA on $0.8 \%$ agarose gel.

\section{Genomic variation study of chromium resistance and} normal strains by RAPD analysis

Purified genomic DNA was subjected to RAPD analysis using ten different primers (are listed in Table No.2) in a thermal Cycler (BioRad). The PCR amplification was performed in 25 $\mu \mathrm{L}$ of each reaction mixture containing $18.2 \mu \mathrm{l}$ nuclease free water, $2.5 \mu \mathrm{l} 10 \mathrm{X}$ taq buffer with $15 \mathrm{mM}$ of $\mathrm{MgCl} 2,2.0 \mu \mathrm{l} 10 \mathrm{mM}$ dNTPs, $1.0 \mu$ l template DNA, $1.0 \mu$ l primer and $0.3 \mu$ l taq DNA polymerase $(3 \mathrm{U} / \mu \mathrm{l})$. The PCR cycle contains the following steps: Initialization denaturation: $94-96^{\circ} \mathrm{C}$ for $1-9$ minutes, 40 cycles of Denaturation step: $94-98^{\circ} \mathrm{C}$ for $20-30$ seconds, Annealing step: $50-65^{\circ} \mathrm{C}$ for $20-40$ seconds, Extension or elongation step: The temperature at this step depends on the DNA polymerase, Final elongation: $70-40^{\circ} \mathrm{C}$ for $5-15$. The PCR product was separated on $2 \%$ agarose gel.

\section{RESULTS AND DISCUSSION}

\section{Bacterial cultures}

Ten highly chromium resistance Bacillus sp. (CSB-1 to10) were isolated from soil samples collected from mine and it's adjacent areas of Sukinda and ten normal Bacillus sp. (NB-1 to 10) were isolated from normal soil sample. The Bacillus sp. is spore-forming gram positive, rod shaped bacteria. They are highly tolerant of adverse ecological condition. Bacillus sp. comprises one of the most common soil bacteria groups. Because of their spore-forming ability, Bacillus strains are readily adaptable to the hostile environments. Bacillus sp. from chromium-contaminated environments are highly resistant to Cr(VI) (Das et al., 2015), and the mechanisms of interaction with chromium have been considered of importance for the development of new cleaning technologies (Viamajala et al. 2007). These chromium resistance bacteria have the exceptional ability to adapt to and colonize the noxious $\mathrm{Cr}(\mathrm{VI})$-polluted environments. These Bacillus sp. have developed the capabilities to protect themselves from $\mathrm{Cr}(\mathrm{VI})$ toxicity. So the present study is aimed to find out the genomic adaptation of Bacillus sp. isolated from chromium contaminated environment and normal environment.

\section{Isolation, purification and quantification of genomic DNA}

The bacterial genomic DNA was isolated and visualized in agarose gel electrophoresis (Fig.1 and Fig.2). The bright DNA band was observed and slight RNA contamination was found in the samples. Genomic DNA constitutes the total genetic information of an organism which transferred from generation to generation. The genetic materials of almost all organisms are DNA, the only exceptions being some viruses that have RNA (ribose nucleic acid). In prokaryotic organisms like bacteria DNA is present as a single, circular chromosome. In some bacteria, extra chromosomal DNA (plasmid) is also present in addition to chromosomal DNA. In eukaryotes, most genomic DNA is located within the nucleus (nuclear DNA) as multiple linear chromosomes of different sizes. The size, number of chromosomes, and nature of genomic DNA varies between different organisms.

Contamination of genomic DNA with RNA may hamper PCR amplification. To make the genomic DNA contamination free
RNAse treatment is required. Therefore, in the present investigation the RNA contaminated DNA samples were purification by RNAse. Agarose gel electrophoresis of these purified DNA bands were depicted in Fig.3 and Fig.4.

Determination of approximate concentration of genomic DNA of 20 Bacillus sp. can be possible by comparing it with $\lambda$ DNA, because the concentration of $\lambda$ DNA is known which can help to determine the exact amount of DNA is present in sample by taking consideration of DNA band position. The molecular weight DNA of 20 Bacillus sp were calculated approximately by comparising the $\lambda$ DNA bands given in Table 2.

\section{Genomic variation study of chromium resistance and} normal strains by RAPD analysis

Screening of the primers for RAPD analysis was performed by taking 10 primers (Table 3). Among all the primers only two OPT 01 and OPT 05 gave the amplification which signifies that some DNA fragments are present in the bacterial DNA having complementary sequence to these two primers. OPT 01 primer is used for both chromium resistant and normal Bacillus DNA samples during PCR amplification The gel electrophoresis result show the presence of lesser bands in normal Bacillus species than those obtained in chromium resistant Bacillus species. The lesser number of band in case of normal Bacillus may be due to the banding of primer to less number of sites on normal Bacillus DNA during PCR amplification. The presence of those DNA fragment band in chromium resistant Bacillus can be used as a molecular marker to identify chromium resistant Bacillus from normal Bacillus (Fig.7).Whereas, the gel electrophoresis results using OPT 05 primer show the lesser bands in chromium resistant Bacillus than those obtained in normal Bacillus species. The lesser number of bands in case of chromium resistant Bacillus may be due to the binding of primer to less number of sites on chromium resistant Bacillus DNA during PCR amplification. The absence of those DNA fragment band can be used as a molecular marker to identify chromium resistant Bacillus from normal Bacillus(Fig.8).

RAPD is faster and technically less demanding than most other molecular typing methods and furthermore, no DNA sequence information is necessary. Also, much smaller amounts of purified DNA are required than for methods such as Restricted Fragment Length Polymerphism(RFLP). The polymorphism within the set of DNA fragments generated has been used in discriminating microorganism both at interspecies and intraspecies level. The RAPD technique has been used previously for strain typing of several microorganisms (Jayarao et al.,1992), including $M$. tuberculosis(Palittaponagarnpim et al. 1993). The RAPD technique was used to obtain a fragment unique to chromium resistant Bacillus species.

\section{CONCLUSION}

In the present study a total of twenty strains of Bacillus species were isolated from soil samples collected from mine and it's adjacent areas of Sukinda, Odisha. Out of twenty highly chromium resistant Bacillus sp. (10) and normal Bacillus sp. (10) were identified from the chromium contaminated and normal soil samples respectively. The genomic DNA was isolated from 20 Bacillus species and the approximate concentration of DNA from 20 Bacillus species were determined by comparing with $\lambda$ DNA. The genomic 
variation study of 10 chromium resistant and 10 normal strains of Bacillus was done by RAPD analysis. Among the 10 primers used only two OPT 01 and OPT 05 gave the amplification. OPT 01 primer gave lesser bands in normal Bacillus species than those obtained in chromium resistant Bacillus species. The presence of those DNA fragment band in chromium resistant Bacillus can be used as a molecular marker to identify chromium resistant Bacillus from normal Bacillus. These chromium resistant Bacillus species after further assessment of their potential to reduce the toxic hexavalent form to its nontoxic trivalent form can be exploited for the bioremediation of toxic and carcinogenic soluble hexavalent chromium containing industrial wastes.

\section{REFERENCES}

[1] Camargo, F. A., Okeke, B. C., Bento, F. M., \& Frankenberger, W. T. (2005). Diversity of chromiumresistant bacteria isolated from soils contaminated with dichromate. Applied soil ecology, 29(2), 193-202.

[2] Desjardin, V., Bayard, R., Lejeune, P., \& Gourdon, R. (2003). Utilisation of supernatants of pure cultures of Streptomyces thermocarboxydus NH50 to reduce chromium toxicity and mobility in contaminated soils. Water, Air, \& Soil Pollution: Focus, 3(3), 153-160.

[3] Jayarao, B. M., D. A. Luther, J. J. E. Dore, Jr. and S. P. Oliver. 1992. Analysis of genetic variation of chromosomal DNA of Streptococcus and Enterococcus species of bovine origin. J. Dairy Sci. 75. (Suppl. 1). 196.

[4] Marsh, T.L. and M.J. McInerney, 2001. Relationship of hydrogen bioavailability to chromate reduction in aquifer sediments. Applied Environ. Microbiol., 67: 1517-1521.

[5] Marsh, T.L. and McInerney, M.J. (2001) Relationship of hydrogen bioavailability to chromate

[6] reduction in aquifer sediments. Applied and Environmental Microbiology, 67: 1517-1521.

[7] Marsh, T.L. and McInerney, M.J. (2001) Relationship of hydrogen bioavailability to chromate

[8] reduction in aquifer sediments. Applied and Environmental Microbiology, 67: 1517-1521.

[9] Marsh, T.L. and McInerney, M.J. (2001) Relationship of hydrogen bioavailability to chromate

[10] reduction in aquifer sediments. Applied and Environmental Microbiology, 67: 1517-1521.

[11] McLean, J., \& Beveridge, T. J. (2001). Chromate reduction by a pseudomonad isolated from a site contaminated with chromated copper arsenate. Applied and Environmental Microbiology, 67(3), 1076-1084.

[12] Sambrook, J., Fritsch, E. F., \& Maniatis, T. (1989). Molecular cloning: a laboratory manual (No. Ed. 2). Cold spring harbor laboratory press.

[13] Viamajala, S., Peyton, B. M., Sani, R. K., Apel, W. A., \& Petersen, J. N. (2004). Toxic effects of chromium (VI) on anaerobic and aerobic growth of shewanella oneidensis MR-1. Biotechnology progress, 20(1), 87-95.

Table: 1 List of primers used in RAPD analysis
\begin{tabular}{|c|c|c|}
\hline Sl. No. & Name of Primer & Sequence of Primer \\
\hline 1 & OPT-1 & $5^{\prime}$-GGGCCACTCA-3 \\
\hline 2 & OPT-2 & $5^{\prime}$-GGAGAGACTC-3' \\
\hline 3 & OPT3 & $5^{\prime}$-TCCACTCCTG-3 \\
\hline 4 & OPT-4 & $5^{\prime}$-CACAGAGGGA-3' \\
\hline 5 & OPT-5 & $5^{\prime}$-GGGTTTGGCA-3' \\
\hline 6 & OPT-6 & $5^{\prime}$-CAAGGGCAGA-3' \\
\hline 7 & OPT-7 & $5^{\prime}$-GGCAGGCTGT-3' \\
\hline 8 & OPT-8 & $5^{\prime}$-AACGGCGACA-3' \\
\hline 9 & OPT-9 & $5^{\prime}$-CACCCCTGAG-3' \\
\hline 10 & OPT-10 & $5^{\prime}$-CCTTCGGAAG-3' \\
\hline 11 & OPT-11 & $5^{\prime}$-TTGCCCGGGA-3' \\
\hline
\end{tabular}

Table: 2 Molecular weight of $\lambda$ DNA

\begin{tabular}{|c|c|c|}
\hline Band position w.r.t $\lambda \mu 1$ digest & DNA (ng/ml) & DNA bp \\
\hline $1^{\text {st }}$ & 271 & 26282 \\
\hline $2^{\text {nd }}$ & 101 & 9824 \\
\hline $3^{\text {rd }}$ & 52.5 & 5090 \\
\hline
\end{tabular}

Table: 3 Screening of primers for RAPD analysis

\begin{tabular}{|c|c|c|c|}
\hline Sl. No. & Name of Primer & Sequence of Primer & Result of amplification \\
\hline 1 & OPT -1 & 5'-GGGCCACTCA-3’' & + \\
\hline 2 & OPT-2 & 5'-GGAGAGACTC-3' & \\
\hline 3 & OPT3 & 5'-TCCACTCCTG-3' & $=$ \\
\hline 4 & OPT-4 & 5'-CACAGAGGGA-3' & - \\
\hline 5 & OPT-5 & 5'-GGGTTTGGCA-3' & + \\
\hline 6 & OPT-6 & 5'-CAAGGGCAGA-3' & - \\
\hline 7 & OPT-7 & 5'-GGCAGGCTGT-3' & _ \\
\hline 8 & OPT-8 & 5'-AACGGCGACA-3' & _ \\
\hline 9 & OPT-9 & 5'-CACCCCTGAG-3' & _ \\
\hline 10 & OPT-10 & 5'-CCTTCGGAAG-3' & _ \\
\hline
\end{tabular}

(+): Positive, (- ): Negative 
International Journal of Trend in Scientific Research and Development (IJTSRD) @ www.ijtsrd.com eISSN: 2456-6470

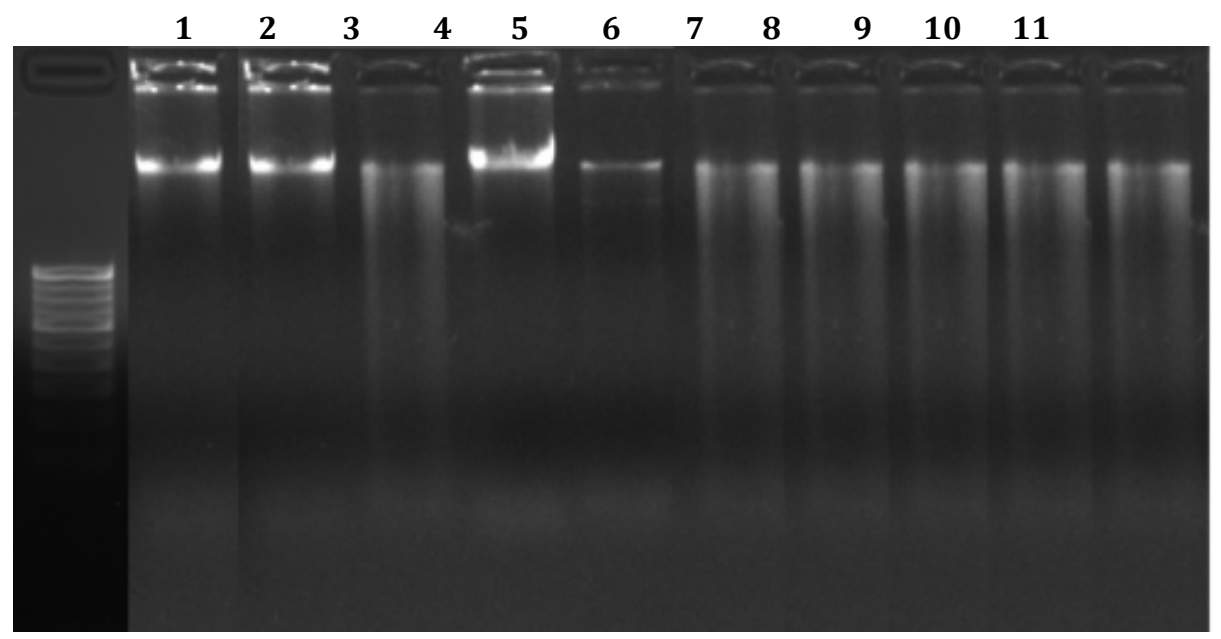

Fig.1: Genomic DNA profile of chromium resistant Bacillus sp.: Lane 1: Ladder (100bp), Lane 2-11: CSB 1-10

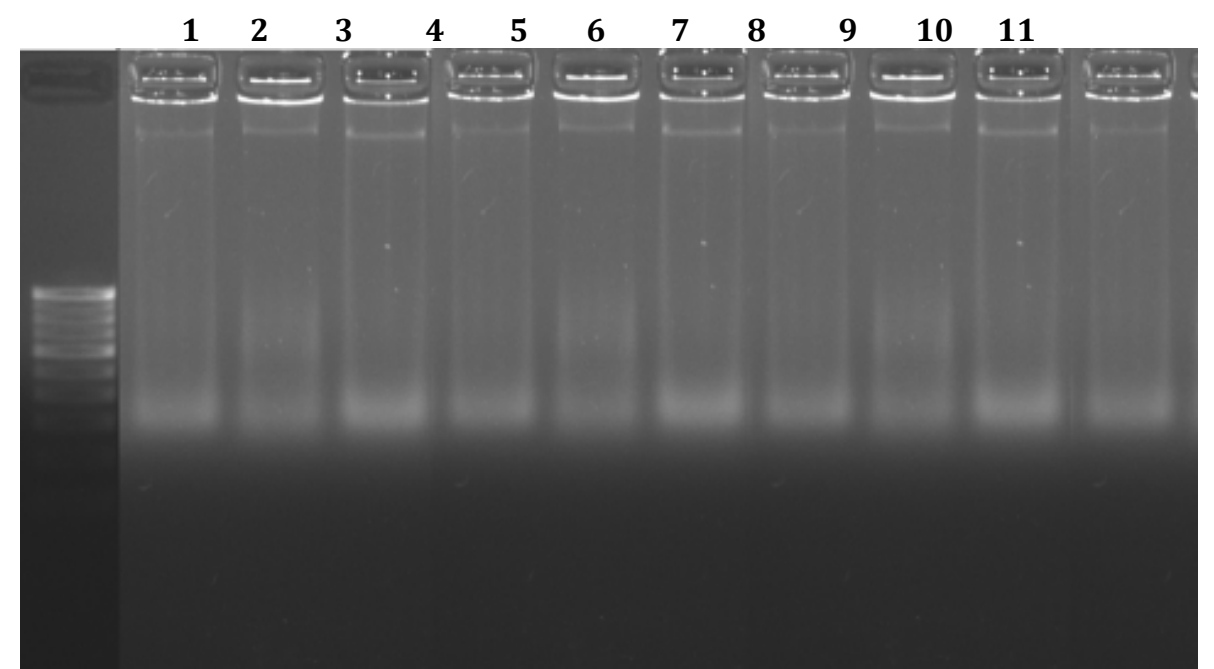

Fig.2: Genomic DNA profile of normal Bacillus sp.: Lane 1: Ladder (100bp), Lane 2-11: NB 1-10

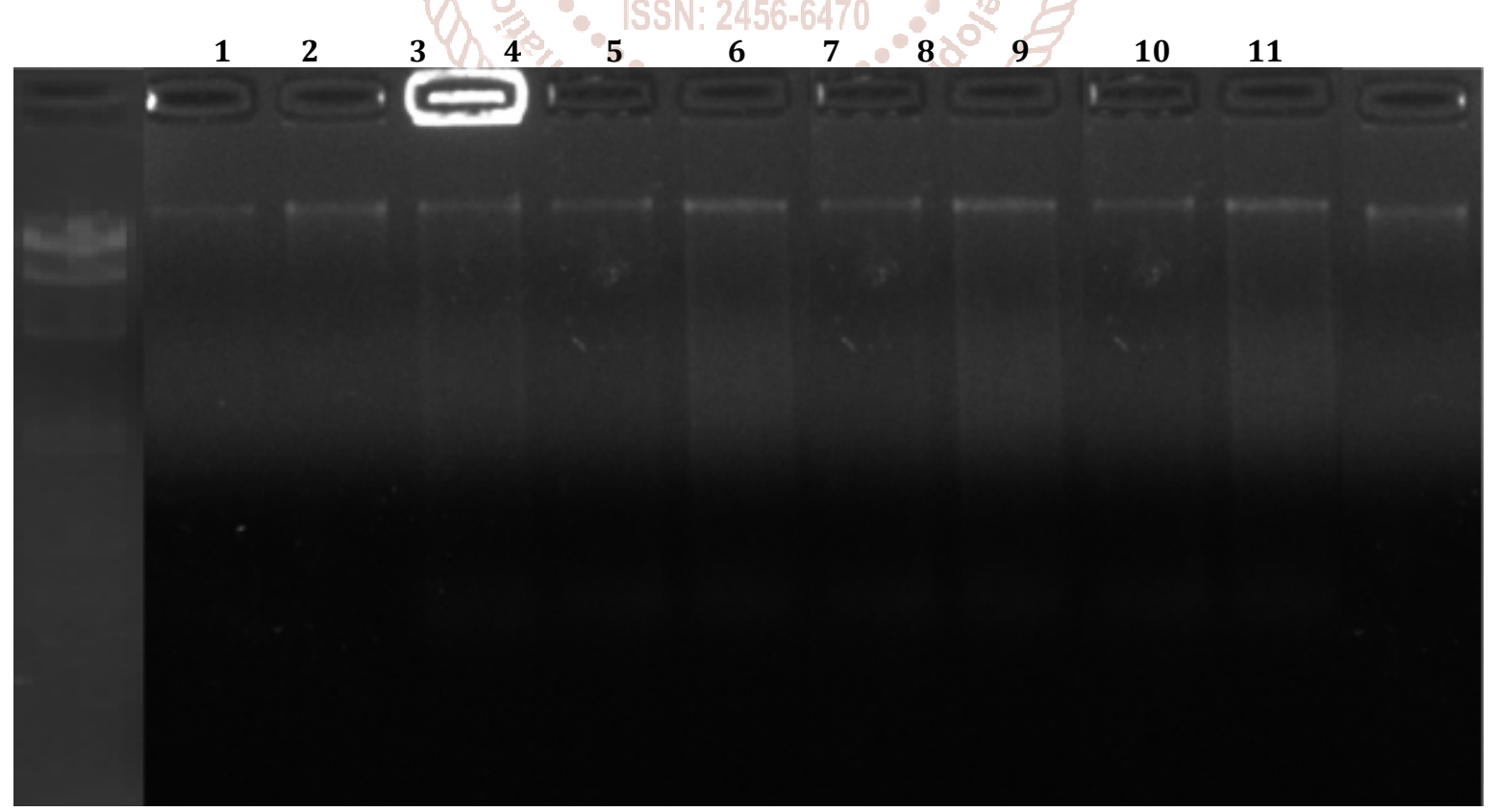

Fig.3: Purified genomic DNA (after RNAase treatment) of chromium resistant Bacillus Sp.: Lane 1: Ladder (100bp) Lane 211: DNA of CSB 1-10 
International Journal of Trend in Scientific Research and Development (IJTSRD) @

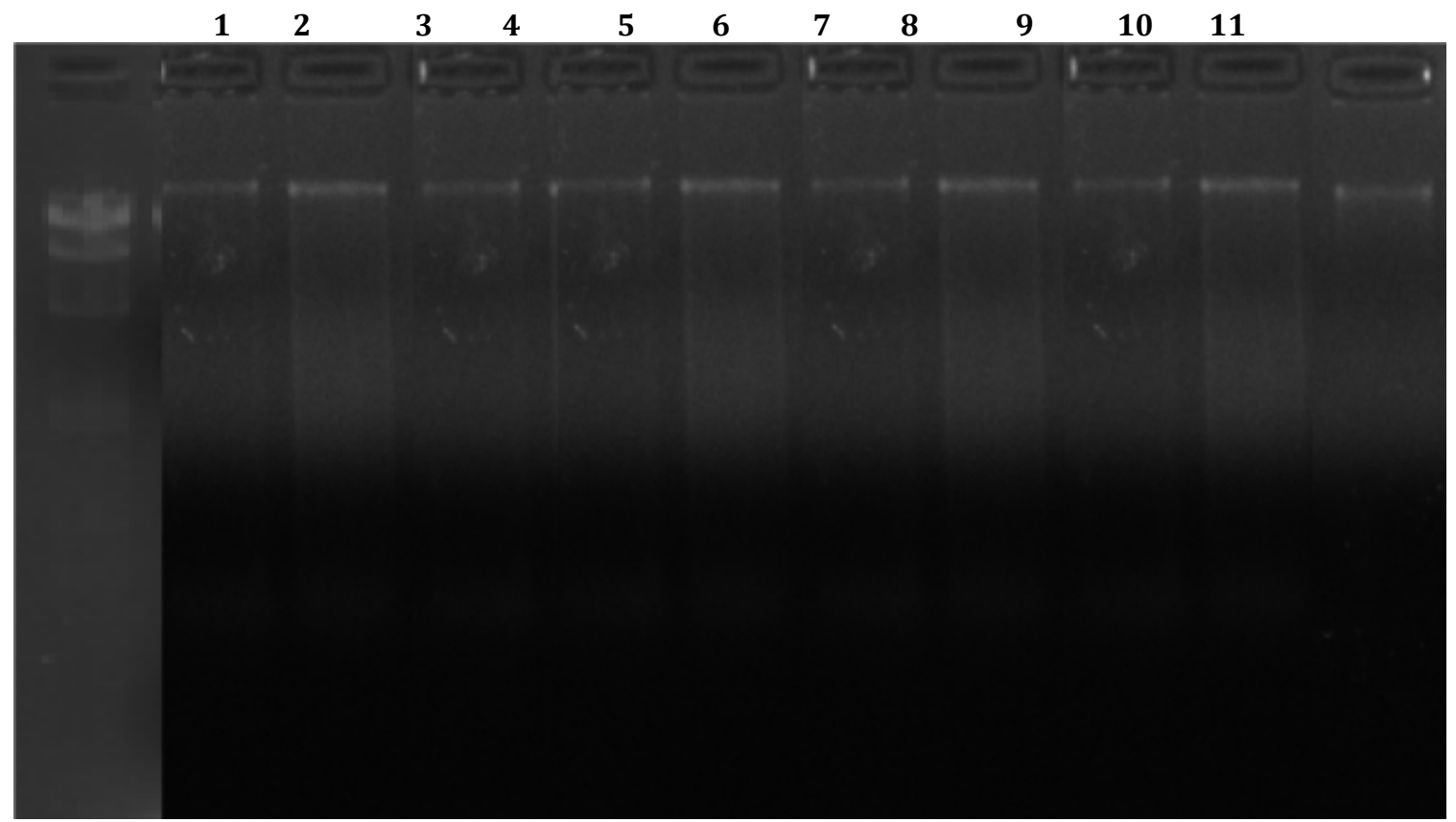

Fig.4: Purified genomic DNA (after RNAase treatment) of normal Bacillus Sp.: Lane 1: Lambda DNA, Lane 2-11: DNA of NB

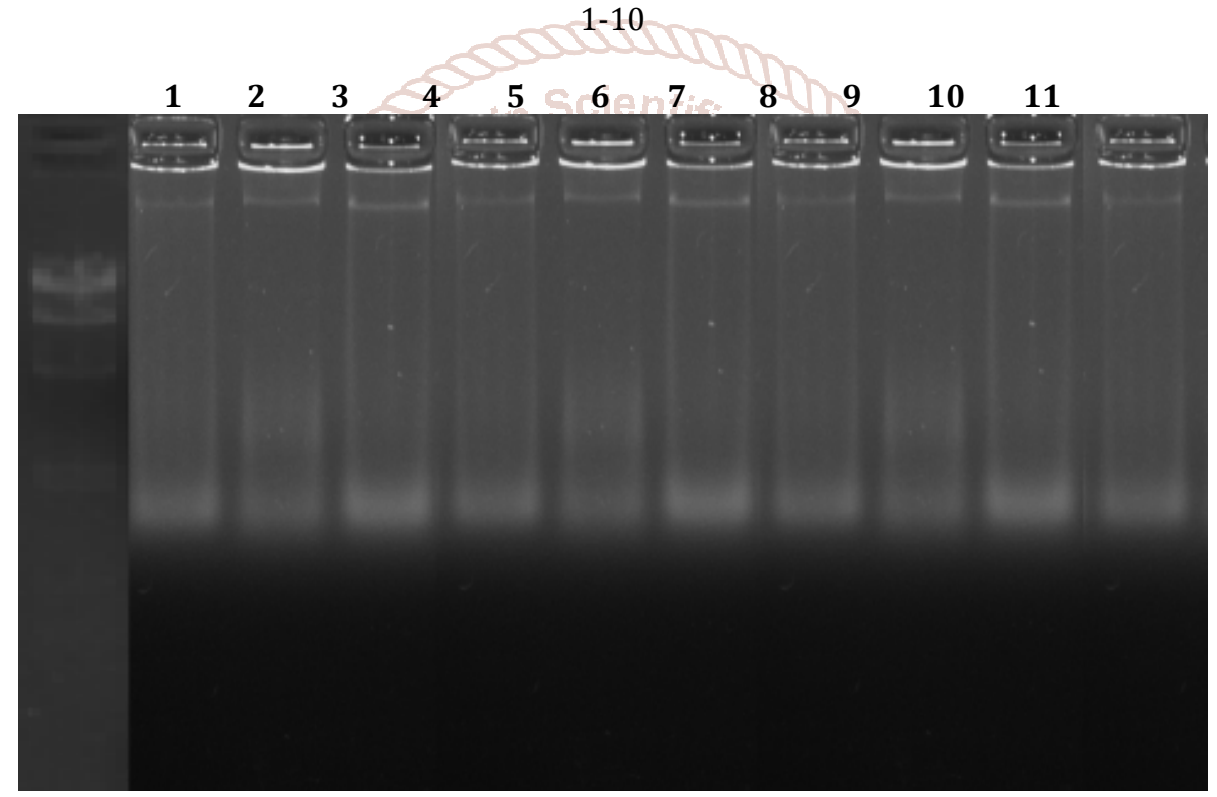

Fig.5: Quantification of genomic DNA obtained from chromium resistant Bacillus sp. against $\lambda$ DNA: Lane 1: $\lambda$ DNA, Lane 211: CSB 1-10

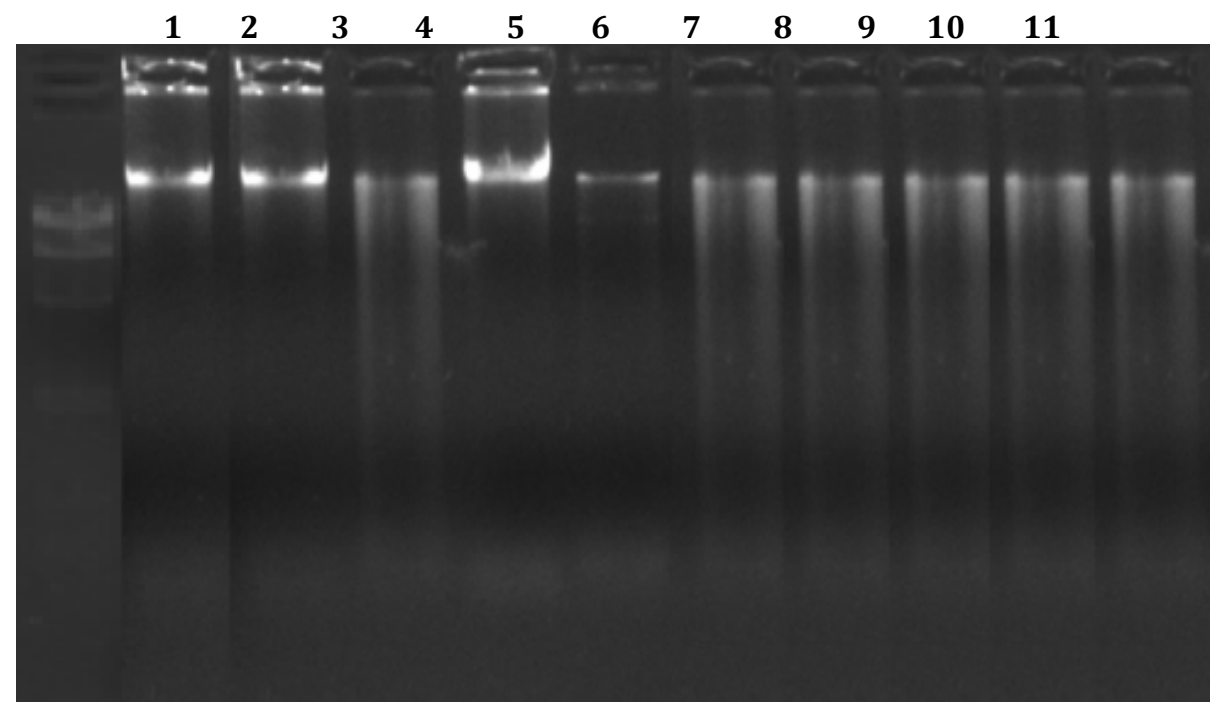

Fig.6: Quantification of genomic DNA obtained from normal Bacillus sp. against $\lambda$ DNA.: Lane 1: $\lambda$ DNA, Lane 2-11: NB 1-10 


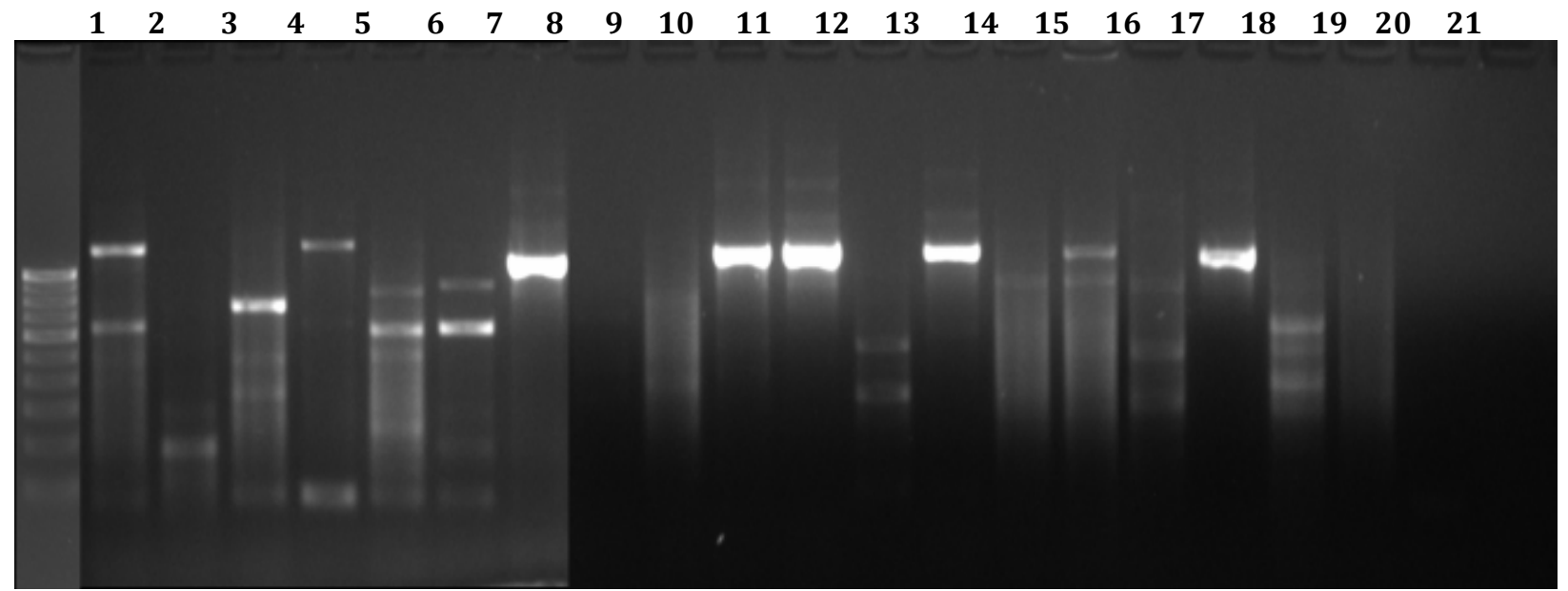

Fig. 7: RAPD-DNA banding patterns of 10 chromium resistant and 10 normal Bacillus sp. using OPT 1 primer; Lane 1 marker DNA of 100bp, Lane 2-11 : CSB 1-10, Lane 12-21: DNA of NB 1-10

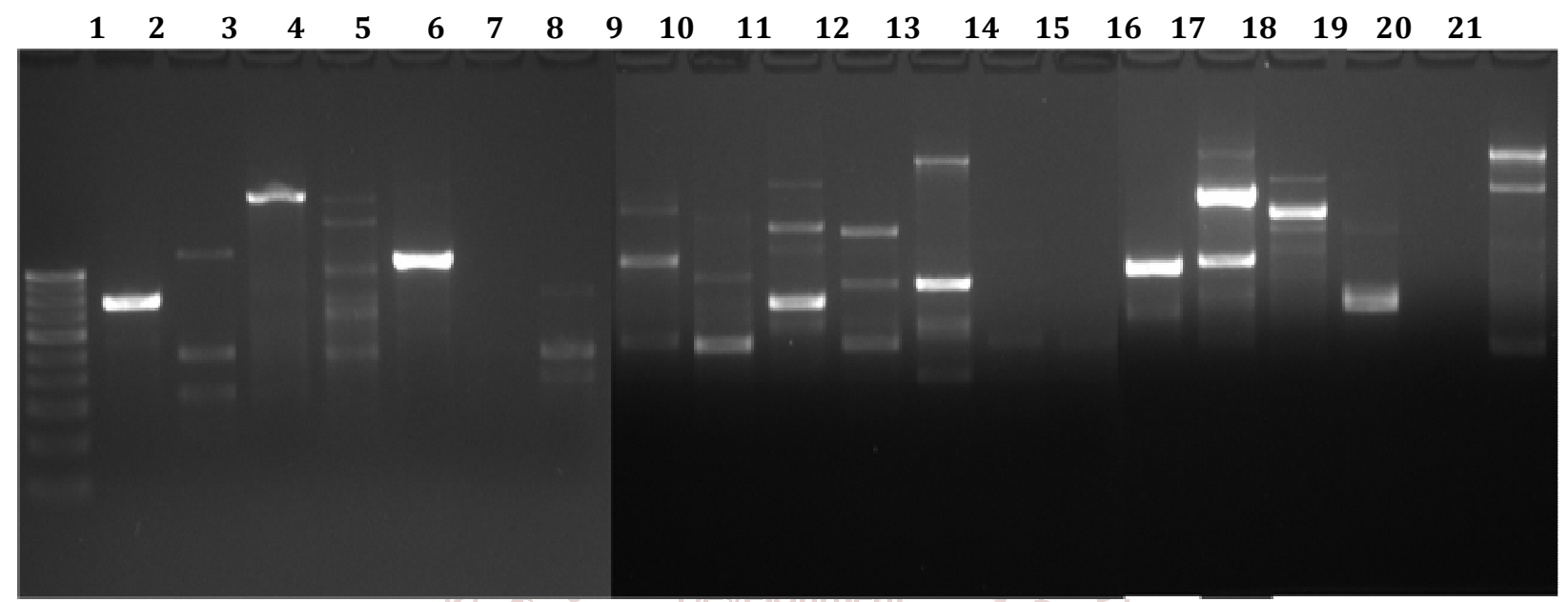

Fig. 8: RAPD-DNA banding patterns of 10 chromium resistant and 10 normal Bacillus sp. using OPT 5 primer, Lane 1 marker DNA of 100bp, Lane 2-11: CSB 1-10, Lane 12-21: NB 1-10 